\title{
Two new species of Colletteidae (Crustacea: Tanaidacea: Tanaidomorpha) from Bransfield Strait, Antarctica
}

\author{
Juliana L. SEGADILHA ${ }^{1, *}$, Kátia C. DOS SANTOS ${ }^{2} \&$ Cristiana S. SEREJO ${ }^{3}$ \\ ${ }^{1,3}$ Laboratório de Carcinologia, Museu Nacional, Universidade Federal do Rio de Janeiro, \\ Quinta da Boa Vista, s/n, CEP 20940-040 Rio de Janeiro, RJ, Brazil. \\ ${ }^{2}$ Laboratório de Carcinologia, Museu de Zoologia, Universidade de São Paulo, Av. Nazaré, 481, \\ Ipiranga, Caixa Postal 42494, CEP 04218-970 São Paulo, SP, Brazil. \\ *Corresponding author: julianasegadilha@gmail.com \\ 2Email: tanaidaceadobrasil@yahoo.com.br \\ ${ }^{3}$ Email: csserejo@acd.ufrj.br \\ ${ }^{1}$ urn:1sid:zoobank.org:author:E9DE1623-8562-49C8-9146-76EF9D8BEC88 \\ ${ }^{2}$ urn:1sid:zoobank.org:author:D7600DAE-60A0-42E6-BA3D-FEECCE7EF666 \\ ${ }^{3}$ urn:1sid:zoobank.org:author:A86225AE-51C8-4D01-9D3E-60FB5B1FE85C
}

\begin{abstract}
Samples from deep benthic areas in the Bransfield Strait, Antarctica, revealed the presence of two new species of Colletteidae: Filitanais elongatus sp. nov. and Macrinella lavradoae sp. nov. Filitanais elongatus sp. nov. resembles F. moskalevi in its habitus; it can, however, be distinguished by characters such as the pleonites and pleotelson with lateral margins parallel and the uropod exopod being longer than half of the first endopod article. Macrinella lavradoae sp. nov. differs from the other species of Macrinella in the shape of the uropod and the pleotelson, with the uropod exopod shorter than the first article of the endopod, the uropod about as long as the pleotelson and the pleotelson with a rounded tip. The number of species of Tanaidacea recorded from Antarctica increases to 162, while the colletteids are now represented by 16 species. Moreover, the diagnosis of the genus Filitanais is herein modified.
\end{abstract}

Keywords. Filitanais, Macrinella, Southern Ocean, King George Island, South Shetland Island.

Segadilha J.L., dos Santos K.C. \& Serejo C.S. 2017. Two new species of Colletteidae (Crustacea: Tanaidacea: Tanaidomorpha) from Bransfield Strait, Antarctica. European Journal of Taxonomy 364: 1-16. https://doi.org/10.5852/ejt.2017.364

\section{Introduction}

The taxonomic research of the Antarctic Tanaidacea Dana, 1849 was initiated at the end of the $19^{\text {th }}$ century, with expeditions such as HMS Challenger (Studer 1884; Beddard 1886a, 1886b; Błażewicz-Paszkowycz 2014). Almost a century later, Shino (1970, 1979) and Sieg (1986) doubled the number of tanaidaceans recorded on the Antarctic shelf (Błażewicz-Paszkowycz 2014). However, until today, tanaidaceans below the shelf-edge are less collected than those of shallow waters, the reason 
being that deep-sea stations in the Southern Ocean are scarce (Błażewicz-Paszkowycz 2014). In the Antarctic region, 160 species of Tanaidacea were reported (Anderson \& Błażewicz-Paszkowycz 2014; Segadilha \& Araújo-Silva 2015), 18 of those from the Bransfield Strait (Błażewicz-Paszkowycz 2014).

The family Colletteidae currently contains 52 species in 16 genera (Anderson 2013; Błażewicz-Paszkowycz 2007; Morales-Núñez et al. 2016). It has a great morphological disparity and heterogeneity and is often well represented in deep-sea samples (Bird 2007). The two genera covered herein have a similar taxonomic history. Both Filitanais Kudinova-Pasternak, 1973 and Macrinella Lang, 1971 were described in the family Paratanaidae Lang, 1949, transferred to Leptognathiidae Sieg, 1976 and later moved to Anarthruridae Lang, 1971 by Sieg (1986) (Anderson 2013). More recently, both genera were transferred to the family Colletteidae based on a morphological phylogenetic analysis (Larsen \& Wilson 2002).

In Antartica, colletteids occur from depths of $90 \mathrm{~m}$ to $7100 \mathrm{~m}$, representing the majority of deep-sea species (Błażewicz-Paszkowycz 2014). Fourteen species in four genera of Colletteidae were reported for the Antarctic region until now: Collettea Lang, 1973 (10 species), Filitanais (two species), Leptognathiella Hansen, 1913 (one species) and Pseudoleptognathia Sieg, 1986 (one species; Anderson \& Błażewicz-Paszkowycz 2014). The present study adds two species, bringing the total to 16 described species, and records for the first time the genus Macrinella from Antarctic waters.

The present study is part of the Brazilian project MABIREH of the International Polar Year (Campos et al. 2008), which yielded the two new aforementioned species of Colletteidae. Moreover, the diagnosis of the genus Filitanais is modified herein.

\section{Material and methods}

MABIREH (Antarctic Marine Life: Biodiversity in Relation to Environmental Heterogeneity in the Admiralty Bay, King George Island, and surrounding areas - CNPq Proc. No. 52.0293/2006-1) is a Brazilian project of the International Polar Year (IPY), which includes the program area of Life Sciences in the Scientific Committee on Antarctic Research (SCAR). Furthermore, it is part of the Marine Life Census projects (CoML), entitled "Census of Antarctic Marine Life - CAML" (Campos et al. 2008).

The material was collected at a depth of $1100 \mathrm{~m}$ in the Bransfield Strait (South Shetland Islands, Antarctica; Fig. 1) in 2008 and 2009. The sediment was collected with a box corer, washed in a mesh size of $0.5 \mathrm{~mm}$, fixed in $4 \%$ borax buffered formalin and subsequently preserved in $70 \%$ alcohol.

All specimens were examined and drawings of the habitus and appendages were made from one dissected specimen of each species. Dissections were made in glycerin using chemically-sharpened tungsten wire needles. All material examined is deposited in the Crustacean Collection of the Museu Nacional, Universidade Federal do Rio de Janeiro, Brazil (MNRJ).

The body length was measured from the tip of the cephalothorax to the apex of the pleotelson. All measurements were made between the largest distances of the articles (length and width). The terminology follows Larsen (2003). Abbreviations are modified after Gardiner (1975):
$\mathrm{A} 1=$ antennules
art. $=$ article
car. $=$ carpus
cph. $=$ cephalothorax
chel. $=$ cheliped
endo. $=$ endopod
exo. $=$ exopod 

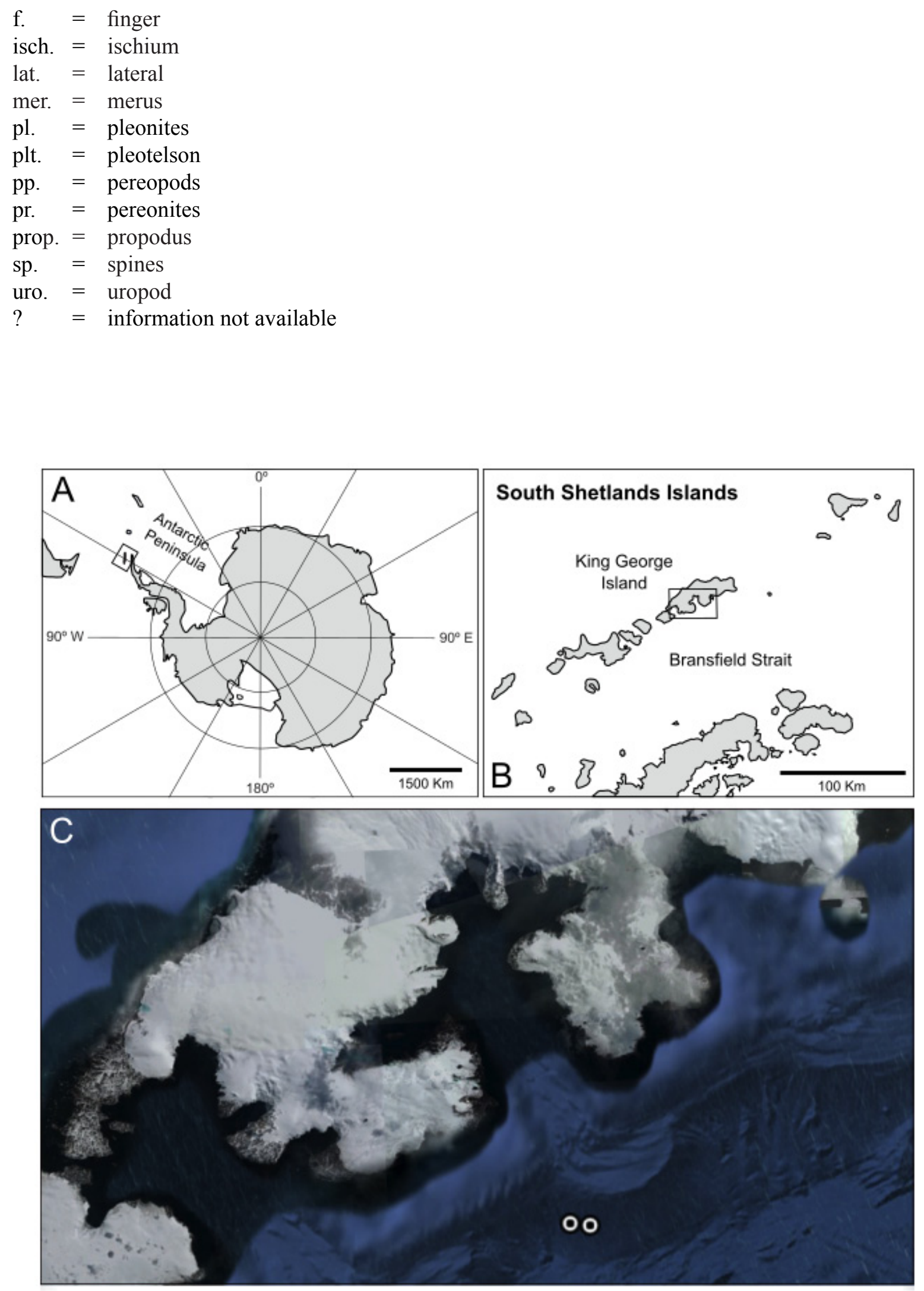

Fig. 1. A. Antarctic Continent. B. South Shetland Islands, King George Island (Admiralty Bay) and Bransfield Strait highlighted. C. Sampling sites in Bransfield Strait. (Source: Google Earth.) 


\title{
Results
}

\author{
Order Tanaidacea Dana, 1849 \\ Suborder Tanaidomorpha Sieg, 1980 \\ Family Colletteidae Larsen \& Wilson, 2002 \\ Genus Filitanais Kudinova-Pasternak, 1973
}

Filitanais Kudinova-Pasternak, 1973: 158.

Filitanais - Larsen 2005: 159-160. — Błażewicz-Paszkowycz 2005: 76. — Anderson 2013: 353.

\section{Type-species}

Filitanais moskalevi Kudinova-Pasternak, 1973.

\section{Species included}

Filitanais curticaudus Kudinova-Pasternak, 1993.

Filitanais elongatus sp. nov.

Filitanais filiformis Larsen, 2005.

Filitanais moskalevi Kudinova-Pasternak, 1973.

Filitanais rebainsi Kudinova-Pasternak, 1975.

Filitanais vulgaris Kudinova-Pasternak, 1981.

Diagnosis (modified after Larsen 2005)

\section{Female}

Body almost nearly cylindrical and filiform. Carapace longer than wide. Eye-lobes and visual elements absent. Pleon long, at least 0.4 times the length of pereon, without lateral edges of dorsal shield. Pleonites and pleotelson not fused. Pleotelson with dorsal plate not covering uropods. Antennule with four articles. Antenna with 5-6 articles. Mandibles with pointed molar. Maxillipedal endites without distal setae; palp article 2 without multifurcate seta. Chelipeds attached via lateral sclerite. Pereopods slender, with coxae, dactylus and unguis not fused to a hook. Pleopods absent in female. Uropods long (about 0.5 times as long as pleotelson), biramous; endopod with two articles; exopod with 1-2 articles.

\section{Remarks}

Larsen (2005) proposed a diagnosis of the genus and considered the "pleonites long, almost as long as the pereonites and pleotelson". According to Larsen (2005), Filitanais vulgaris, even with a long pleon, was classified within the genus Collettea because of its broad mandibular molar. Larsen (2005) also wrote that F. curticaudus might not belong to Filitanais because of its short pleon, about 0.4 times the length of the pereon.

On the other hand, Błażewicz-Paszkowycz (2005: key) characterized Filitanais as having a pleon longer than half the length of the pereon, and the pleotelson clearly longer than wide. Our examination of the six species of the genus, however, revealed that the pleon of $F$. moskalevi is only 0.4 times the length of the pereon, which casts doubt on the inclusion of this species within the genus. Alternatively, we propose to change the diagnosis of Filitanais as having a pleon at least 0.4 times the length of the pereon. 


\section{Filitanais elongatus sp. nov. urn:1sid:zoobank.org:act:2BB6BAF1-E2AC-4EA3-8EED-BC62C46F296A}

Figs $1-3$

\section{Diagnosis (based on females)}

Body about 13 times longer than wide; pereonite 2 four times longer than pereonite 1; pereopod 1-3 carpus with three spiniform setae distally and propodus with one spiniform ventral seta; pereopod 1-6 ischium without seta; pleon about 0.6 times as long as pereon; pleotelson square, as long as wide; uropod as long as pleotelson; uropod exopod longer than first article of endopod.

\section{Etymology}

The specific epithet refers to the long second pereonite, about four times longer than the first pereonite in species of Filitanais.

\section{Material examined}

\section{Holotype}

ANTARCTICA: + , dissected, adult non-ovigerous, length $1.9 \mathrm{~mm}$, Bransfield Strait, station \#2, 62 $2^{\circ} 17^{\prime} 33.4^{\prime \prime} \mathrm{S}, 58^{\circ} 18^{\prime} 12.6^{\prime \prime} \mathrm{W}, 1.147 \mathrm{~m}$ deep, 6 Dec. 2008 (MNRJ 24443).

\section{Paratype}

ANTARCTICA: 1 , adult non-ovigerous, length $1.8 \mathrm{~mm}$, other data as for the holotype (MNRJ 26238).

\section{Description}

Body (Fig. 2). About 13 times as long as wide. Cephalothorax oval, 1.6 times as long as wide; eyelobes absent. Pereonites 2-6 longer than wide. All pereonites with lateral setae. Pereonite 1 shortest, about 0.6 times longer than wide. Pereonite 2 longest, about 1.8 times as long as wide. Pereonite 3 as long as pereonite 4, about 1.4 times as long as wide. Pereonite 5 slightly longer than pereonite 6 , both about 1.3 times as long as wide. Pleon (Fig. 2) long, about $30 \%$ of body length. All pleonites sub-equal in size, with first two pleonites slightly longer than others ( 0.7 and 0.6 times longer than wide). Pleonite 5 with lateral simple seta. Pleotelson square, about as long as wide, with dorsal plate not covering uropods; one pair of lateral and one pair of terminal simple setae. Apex pointed.

Antennule (Fig. 2). With four articles, slightly shorter than cephalothorax. Article 1 longest, about 2.3 times as long as wide, with one simple and four penicillate outer setae. Article 2 about 1.4 times as long as wide, one inner distal penicillate seta and one simple and two penicillate outer setae. Article 3 stout, as long as wide, with two simple and one penicillate distal setae. Article 4 slender, about 2.0 times as long as wide, with five simple terminal setae and one aesthetasc.

Antenna (Fig. 2). With five articles. Article 1 short and fused to the cephalothorax, naked. Article 2 as long as wide, with one simple long outer seta. Article 3 longest, about 2.9 times as long as wide, with two simple and one penicillate inner distal setae and two outer distal penicillate setae. Article 4 narrow, 2.9 times as long as wide, with one distal simple seta. Article 5 minute, with six simple terminal setae.

MouthParTs. Labrum (Fig. 2) rounded and setulose. Mandible molar process longer than incisor and narrow, distal part with three small spines. Left mandible (Fig. 2) lacinia mobilis in the shape of a single blunt spine, shorter than incisor; incisor with pointed distal margin. Right mandible (Fig. 2) incisor crenulated dorsally and pointed distally. Labium (Fig. 2) simple, with naked lobes. Maxillule (Fig. 3) endite with ten distal spiniform setae. Palp not recovered. Maxilla (Fig. 3) with oval shape elongated. Maxilliped (Fig. 3) basis wider than endite, rectangular and partly fused. Endites not fused, with one 


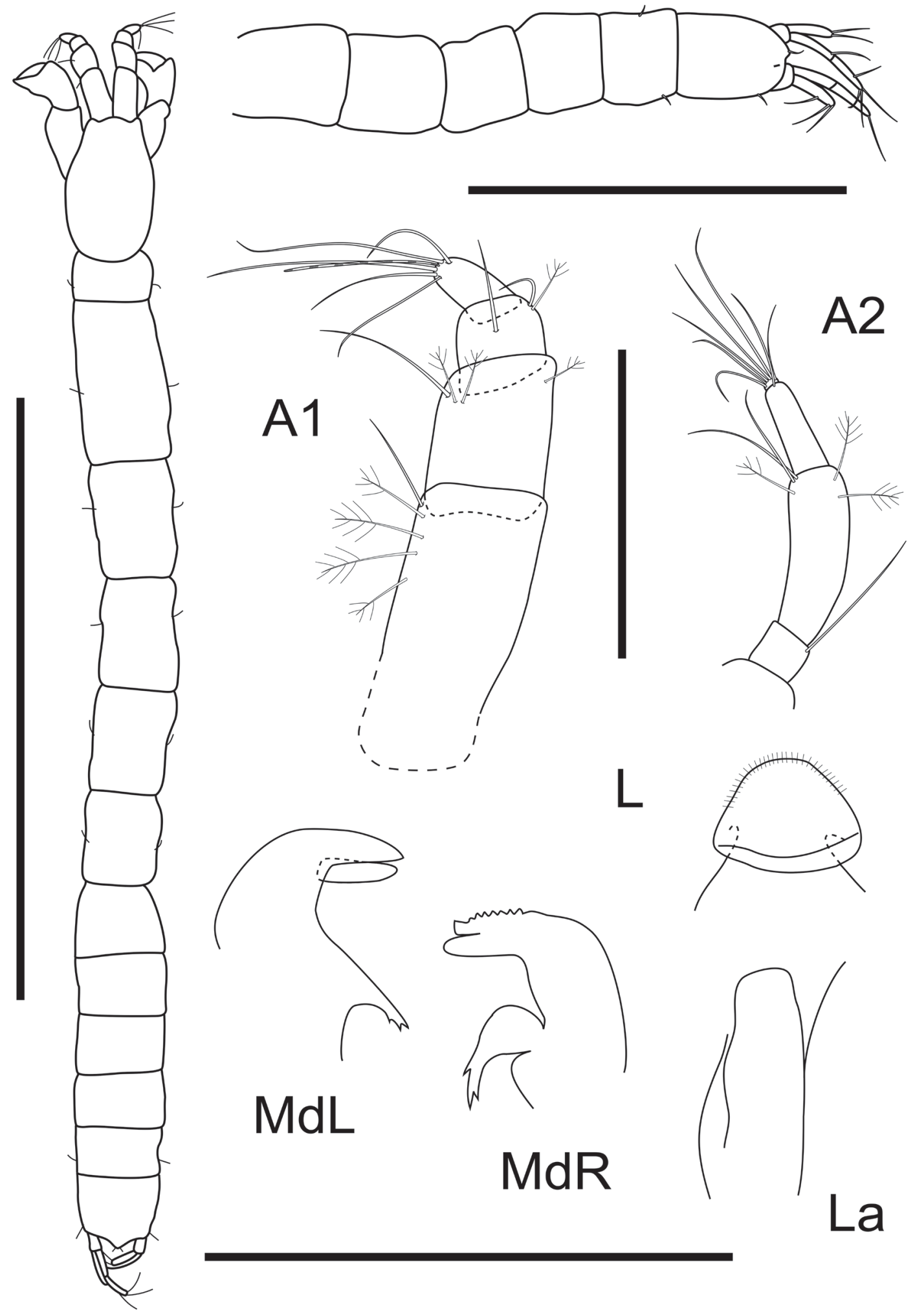

Fig. 2. Filitanais elongatus sp. nov., holotype, $~$ (MNRJ 24443), length $1.9 \mathrm{~mm}$, body in dorsal view. Scale bar $=1.0 \mathrm{~mm}$. Pleon lateral view, scale bar $=0.5 \mathrm{~mm}$. Abbreviations: A1 $=$ antennules; A2 $=$ antenna; $\mathrm{L}=$ labrum; $\mathrm{MdL}=$ left mandible; $\mathrm{MdR}=$ right mandible; $\mathrm{La}=$ labium. Scale bars $=0.1 \mathrm{~mm}$. 
distal tubercular process each. Palp article 1 smooth; article 2 with three inner and one outer seta; article 3 with three inner setae; article 4 with five inner setae (one short, four long). Epignath not recovered.

ChelIPED (Fig. 3). Basis unequally divided by long prominent sclerite, longer than carpus, proximal part narrow, distal part wide, attached to cephalothorax via large sclerite. Merus triangular, with one simple seta ventrally. Carpus about 1.8 times as long as wide, no carpal shield, with two ventral and one dorsal simple setae. Propodus about 1.8 times as long as wide, with three simple setae on inner view. Fixed finger with four simple setae on cutting edge and two simple ventral setae. Dactylus slightly curved and smooth, as long as fixed finger.

PeREopod 1 (Fig. 3). Coxa present with one simple seta. Basis stout and naked, about 2.2 times as long as wide. Ischium naked. Merus about 1.4 times as long as wide, with one simple and one long spiniform distoventral setae. Carpus longer than merus, with three spiniform setae distally. Propodus shorter than merus and carpus combined, with one minute distodorsal and one spiniform distoventral setae. Dactylus 0.6 times as long as unguis. Dactylus and unguis combined longer than propodus.

PeREOPod 2 (Fig. 3). Similar to pereopod 1, except coxa naked; carpus with one distodorsal and two distoventral spiniform setae; propodus with one spiniform distoventral seta.

PeREOPOD 3 (Fig. 3). Similar to pereopod 2, except, dactylus and unguis combined as long as propodus.

Pereopod 4 (Fig. 3). More slender than pereopod 1-3. Coxa absent. Basis about 3.1 times as long as wide, naked. Ischium, with one simple seta. Merus about 1.7 times as long as wide, with two spiniform distoventral setae. Carpus longer than merus, with one simple and three spiniform setae distally. Propodus shorter than merus and carpus combined, with one minute and one spiniform distodorsal setae, and two spiniform distoventral setae. Dactylus 1.3 times as long as unguis. Dactylus and unguis combined longer than propodus.

Pereopod 5 (Fig. 3). Similar to pereopod 4, except ischium with two ventral setae.

Pereopod 6 (Fig. 3). Similar to pereopod 4, except carpus with one simple and four spiniform distal setae. Propodus with four distal spiniform setae. Dactylus 0.8 times shorter than unguis.

Pleopods. Absent.

UROPOD (Fig. 3). As long as pleotelson. Basal article long and naked, about 1.1 times as long as wide. Exopod uniarticulate, longer than endopod first article, with one simple medial and two long simple setae apically. Endopod biarticulate, first article longer than second, with one simple subdistal seta; second article with one simple medial seta, and one penicillate and five simple terminal setae.

\section{Remarks}

The diagnostic characters used to identify species of Filitanais are the shape of the pleotelson and the pleonites as well as the length of the uropodal exopod. The mouthparts and the articulation of the uropodal exopod are not reliable characters for species separation (Larsen 2005). The main differences between the six species of Filitanais are shown in Table 1. Filitanais elongatus sp. nov. resembles F. moskalevi in habitus, but it can be distinguished by the pleonites and the pleotelson with lateral margins parallel, the merus of pereopod 1 with two setae and the uropod exopod longer than half of the first article of the endopod.

Filitanais elongatus sp. nov. differs from F. filiformis in having:

(i) antennules slightly shorter than the cephalothorax (instead of equally long); 


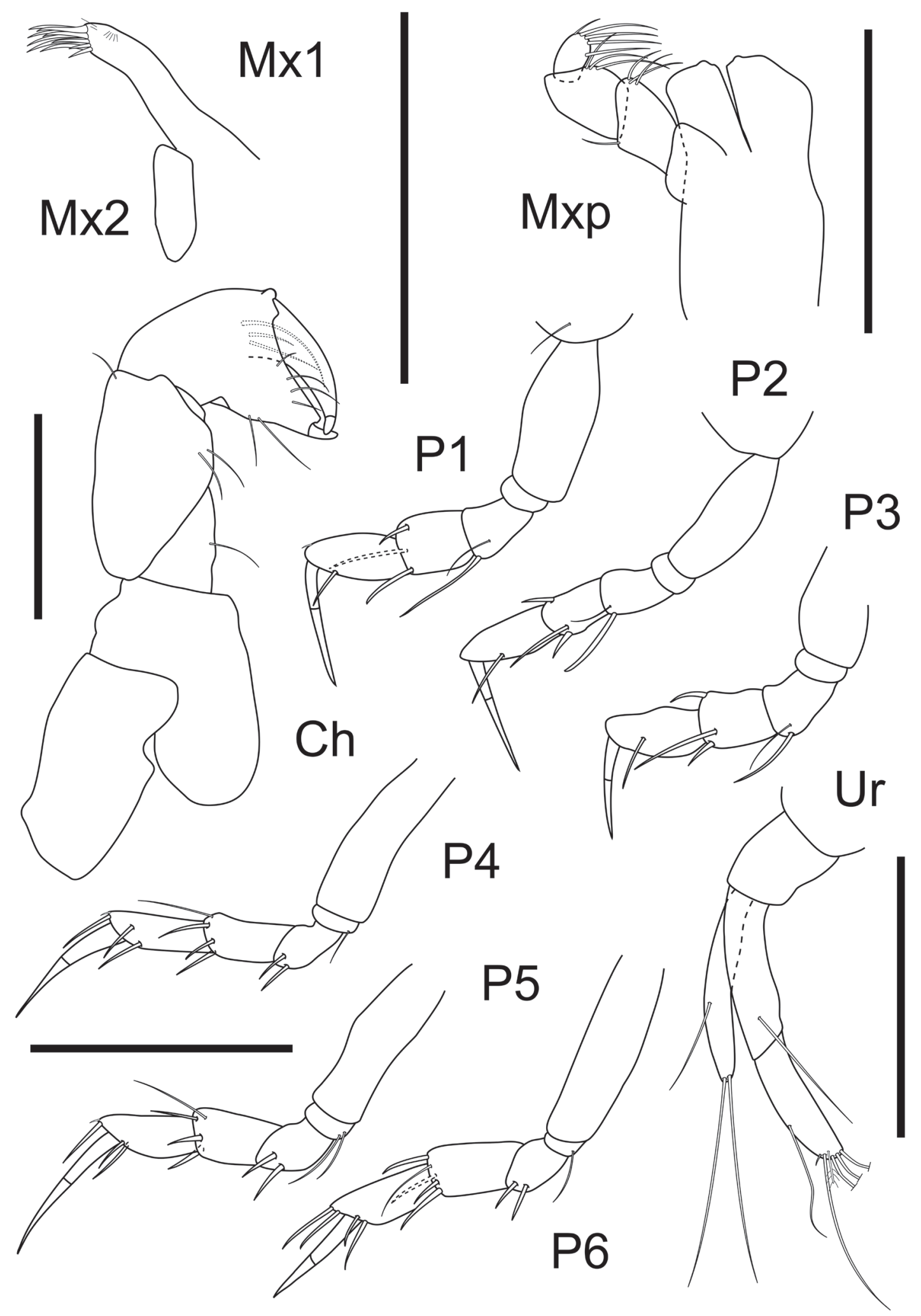

Fig. 3. Filitanais elongatus sp. nov., holotype, $q$ (MNRJ 24443), length $1.9 \mathrm{~mm}$. Abbreviations: Mx $1=$ maxilulle; $\mathrm{Mx} 2=$ maxilla; $\mathrm{Mxp}=$ maxilliped; $\mathrm{Che}=$ cheliped; $\mathrm{P} 1=$ pereopod $1 ; \mathrm{P} 2=$ pereopod $2 ; \mathrm{P} 3=$ pereopod 3; P4 = pereopod 4; P5 = pereopod 5; P6 = pereopod 6; Ur $=$ uropod. Scale bars $=0.1 \mathrm{~mm}$. 


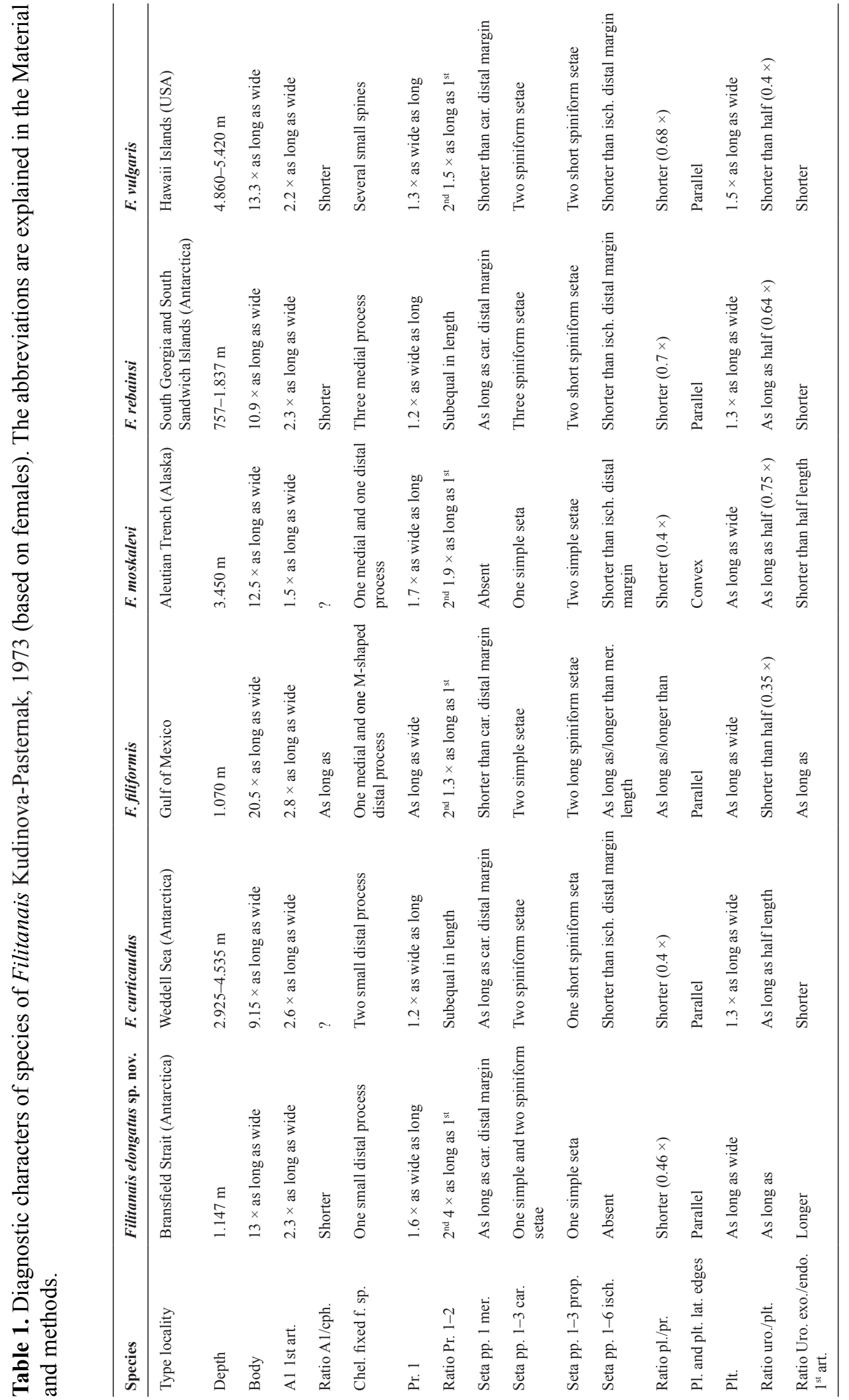


(ii) pereonite 1 wider than long (instead of equally long);

(iii) the pleonites combined about 0.6 times as long as pereonites length (instead of as long as or longer);

(iv) the uropod exopod longer than half of the first article of endopod (instead of as long as).

The new species differs from $F$. vulgaris by:

(i) the length of pleotelson (as long as wide in F. elongatus sp. nov. and 1.5 times longer than wide in F. vulgaris);

(ii) the slender uropod, as long as the length of the pleotelson, instead of shorter than half of the pleotelson;

(iii) the seta of pereopod 1 merus longer than the distal margin of the carpus.

Filitanais elongatus sp. nov. is distinct from both Antarctic species (F. rebainsi and F. curticaudus) in:

(i) pereonite 2 four times longer than pereonite 1 , instead of sub-equal in length;

(ii) the uropod exopod longer than the first article of the endopod, instead of shorter;

(iii) the pleotelson as long as wide (instead of 1.3 and 1.5 times longer than wide, respectively).

\section{Distribution}

Bransfield Strait, Antarctica, $1.147 \mathrm{~m}$.

Genus Macrinella Lang, 1971

\section{Type-species}

Paranarthrura clavipes Hansen, 1913.

\section{Species included}

Macrinella clavipes (Hansen, 1913).

M. lavradoae sp. nov.

Macrinella lavradoae sp. nov. urn:1sid:zoobank.org:act:74E71132-4585-49FD-8773-CD1F739E7872

Figs 1, 4-5

Diagnosis (based on female)

Pereonites with convex lateral edges. Pleon narrower than pereon. Pleotelson pentagonal, with rounded projection at the posterior edge. Antennule 0.6 times longer than carapace. All pereopods with coxae present. Pereopods 1-3 merus with short seta, not reaching carpus proximal edge. Pereopods 2-3 propodus with one penicillate terminal setae. Pleopods absent. Uropod exopod uniarticulate; endopod robust, with two articles.

\section{Etymology}

The new species is named in honour of Dr Helena Passeri Lavrado (IB/UFRJ) in recognition of her incentive and encouragement to the first author to initiate taxonomic studies on tanaidaceans. Moreover, she coordinates the subproject MABIREH and is a member of the committee board of the Instituto Nacional de Ciência e Tecnologia Antártico de Pesquisas Ambientais (INCT-APA).

\section{Material examined}

\section{Holotype}

ANTARCTICA: + , dissected, adult non-ovigerous, length $1.9 \mathrm{~mm}$, Bransfield Strait, station \#3, 62¹7'26.4" S, 58 19'49.5" W, 1.153 m, 5 Dec. 2009 (MNRJ 24445). 


\section{Description}

Body (Fig. 4). About eight times as long as wide (broken in the pereonite 4). Cephalothorax oval, about 1.3 times as long as wide; eyelobes absent. All pereonites with convex lateral edges. Pereonite 1 shortest, 0.8 times longer than wide. Pereonites 2 and 3 longest, about as long as wide. Pereonite 5 slightly longer than pereonite 6, both about as long as wide. Pleon (Fig. 4) short, about $19 \%$ of body length, narrower than pereon. All pleonites sub-equal in size, wider than long. Pleonite 5 with lateral simple seta. Pleotelson pentagonal, slightly wider than long, with rounded projection at the posterior edge and with one pair of lateral and two pairs of terminal simple setae.

Antennule (Fig. 4). With four articles, shorter than cephalothorax (about 0.6 times as long as carapace). Article 1 longest, about 1.8 times as long as wide, with one simple and five penicillate inner distal setae. Article 2 about as long as wide, with one simple and three penicillate inner distal setae. Article 3 stout, about 0.8 times as long as wide, with one simple and two penicillate outer distal setae. Article 4 slender, twice as long as wide, with five simple and two penicillate terminal setae.

Antenna (Fig. 4). With six articles. Article 1 short and fused to the cephalothorax, naked. Article 2 as long as wide, naked. Article 3 about 0.8 times as long as wide, with one simple outer distal seta. Article 4 longest, about 2.8 times as long as wide, with two simple and three penicillate distal setae. Article 5 narrow, 1.5 times as long as wide, with one distal simple seta. Article 6 minute, with five simple terminal setae.

MouthParTs. Labrum (Fig. 4) rounded and setulose. Mandible molar process longer than incisor and relatively broad, distal part with few blunt denticles. Left mandible (Fig. 4) lacinia mobilis rounded, in the shape of two blunt spines, as long as incisor; incisor with two blunt denticles. Right mandible (Fig. 4) incisor with three blunt denticles. Labium not recovered. Maxillule (Fig. 5) endite with nine distal spiniform setulose setae. Palp slender, with two distal setae. Maxilla not recovered. Maxilliped (Fig. 5) basis rectangular and partly fused. Endites not fused, with one distal short seta and one small tubercular process. Palp article 1 smooth; article 2 with three inner penicillate and one outer simple setae; article 3 with three inner penicillate and one simple setae; article 4 with five inner setae (one simple, four penicillate) and one outer simple seta. Epignath not recovered.

CheLIPED (Fig. 5). Basis unequally divided by long prominent sclerite, shorter than carpus, proximal part wide, distal part narrow, attached to cephalothorax via large sclerite. Merus triangular, with one simple ventral seta. Carpus about 1.9 times as long as wide, no carpal shield, with two simple ventral and one minute dorsal setae. Propodus about three times as long as wide, with two simple setae on inner view. Fixed finger with three simple setae on cutting edge and two ventral simple setae. Dactylus slightly longer than fixed finger.

Pereopod 1 (Fig. 5). Coxa present (not figured). Basis slender and naked, four times longer than wide. Ischium with one simple seta. Merus about 1.7 times as long as wide, with one spiniform distoventral seta. Carpus longer than merus, with two simple and two spiniform distal setae. Propodus shorter than merus and carpus combined, with one spiniform distoventral seta and a row of spinules terminal setae. Dactylus 0.8 times as long as unguis. Dactylus and unguis combined as long as propodus.

Pereopod 2 (Fig. 5). Coxa present. Basis slender and naked, about 4.7 times as long as wide. Ischium with one simple seta. Merus about 1.2 times as long as wide, with one spiniform distoventral seta. Carpus longer than merus, with two distoventral and two distodorsal spiniform setae. Propodus shorter than merus and carpus combined, with one spiniform distoventral, a row of spinules and one penicillate terminal setae. Dactylus 0.7 times as long as unguis. Dactylus and unguis combined longer than propodus. 


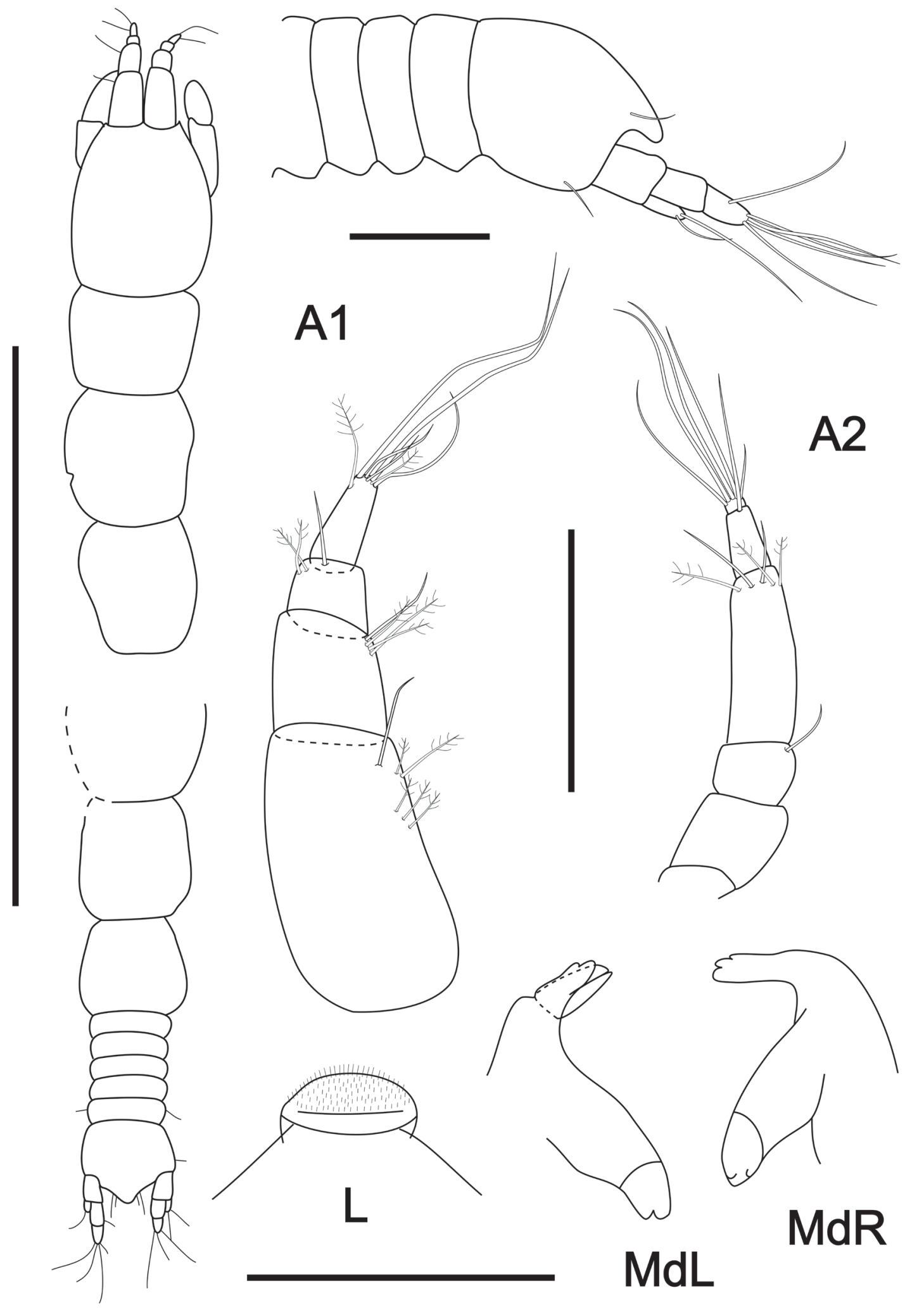

Fig. 4. Macrinella lavradoae sp. nov., holotype, $q$ (MNRJ 24445), length $1.9 \mathrm{~mm}$, body in dorsal view. Scale bar $=1.0 \mathrm{~mm}$. Pleon in lateral view. Abbreviations: $\mathrm{A} 1=$ antennules; $\mathrm{A} 2=$ antenna; $\mathrm{L}=$ labrum; $\mathrm{MdL}=$ left mandible; $\mathrm{MdR}=$ right mandible. Scale bars $=0.1 \mathrm{~mm}$. 


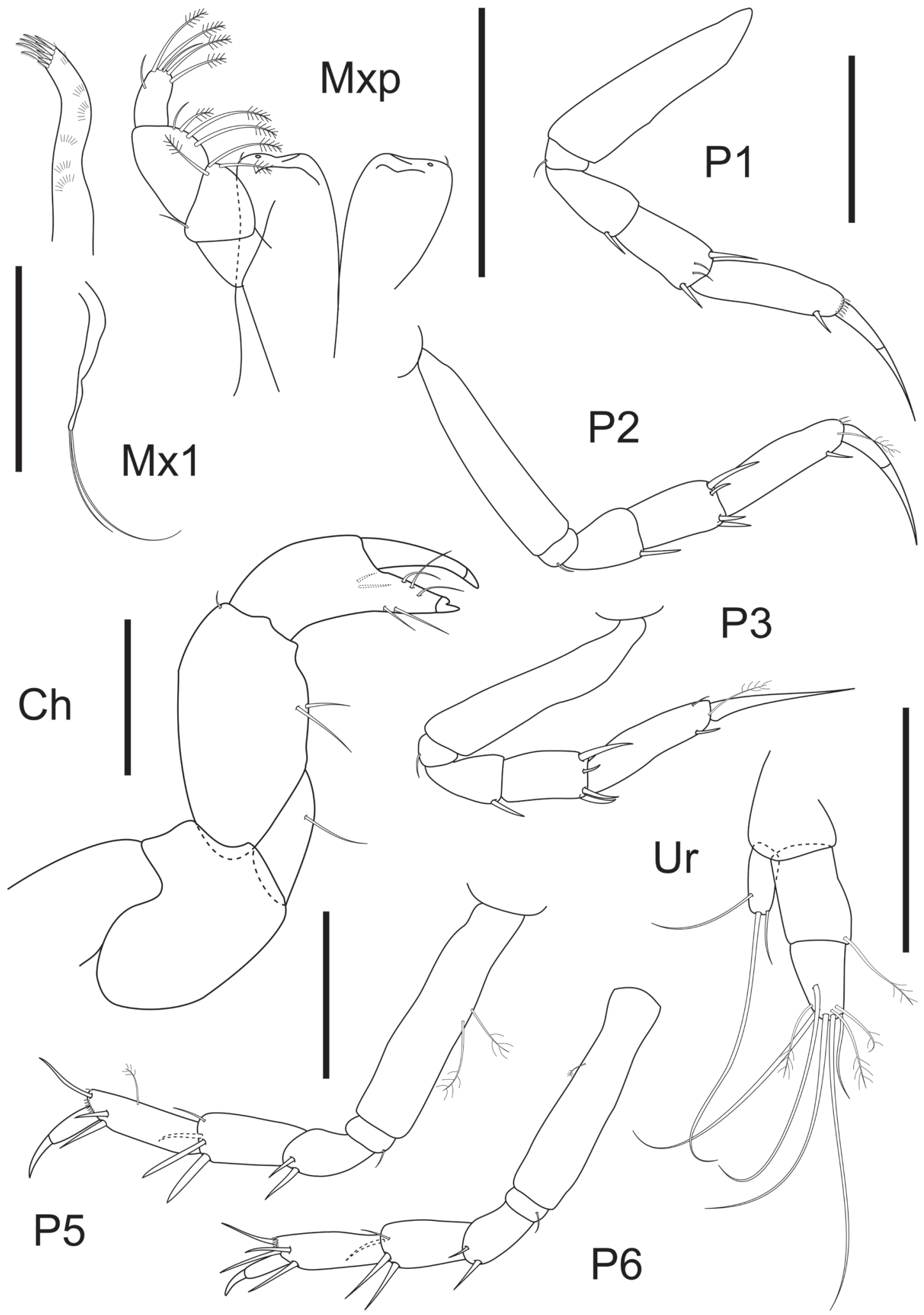

Fig. 5. Macrinella lavradoae sp. nov., holotype, $\varnothing$ (MNRJ 24445), length $1.9 \mathrm{~mm}$. Abbreviations: Mx $1=$ maxilulle; $\mathrm{Mxp}=$ maxilliped; $\mathrm{Che}=$ cheliped $\mathrm{P} 1=$ pereopod $1 ; \mathrm{P} 2=$ pereopod $2 ; \mathrm{P} 3=$ pereopod $3 ; \mathrm{P} 5=$ pereopod 5; P6 = pereopod 6; $\mathrm{Ur}=$ uropod. Scale bars $=0.1 \mathrm{~mm}$. 
PeReopod 3 (Fig. 5). Similar to pereopod 2, except merus about 1.5 times as long as wide; propodus with one simple distodorsal, one spiniform distoventral and one penicillate terminal setae.

PeReopod 4. Missing.

Pereopod 5 (Fig. 5). Thicker than pereopods 1-3. Coxa present. Basis about 4.3 times as long as wide, with two midventral penicillate setae. Ischium short, with one simple seta. Merus about 1.7 times as long as wide, with two spiniform distoventral setae. Carpus longer than merus, with one simple and three spiniform distal setae. Propodus shorter than merus and carpus combined, with one penicillate mid-dorsal seta, one spiniform distodorsal and two distoventral setae. Dactylus about 1.1 times as long as unguis. Dactylus and unguis combined shorter than propodus.

PeREOPOD 6 (Fig. 5). Similar to pereopod 2, except for basis with one penicillate dorsal seta; propodus with three distodorsal and one spiniform distoventral setae.

Pleopods. Absent.

UROPOD (Fig. 5). Shorter than pleotelson. Basal article naked. Exopod uniarticulate, longer than half length of endopod first article, with one medial and two terminal simple setae. Endopod biarticulate, first article longer than second article, with one penicillate distal seta; second article with one simple medial, three penicillate and four simple terminal setae.

\section{Remarks}

The genus Macrinella is currently monotypic and includes Macrinella clavipes recorded from Davis Strait, Greenland (Lang 1971).

Macrinella lavradoae sp. nov. is distinct from M. clavipes in having:

(i) maxilliped endites with only one distal small tubercular process;

(ii) the dactylus of pereopods 5-6 short (1.2 times longer than wide);

(iii) pleopods absent;

(iv) the uropod exopod shorter than the first article of the endopod;

(v) the uropod about as long as the pleotelson;

(vi) the pleotelson with a rounded tip.

Macrinella lavradoe sp. nov. is a new record of the genus for Antarctica.

\section{Distribution}

Bransfield Strait, Antarctica, $1.153 \mathrm{~m}$.

\section{Discussion}

Two new species of the family Colletteidae from Bransfield Strait are described herein: Filitanais elongatus sp. nov. and Macrinella lavradoae sp. nov. Eighteen tanaidacean species had previously been recorded from the Bransfield Strait (Błażewicz-Paszkowycz 2004). Hence, this work raises the list of Tanaidacea species known for Admiralty Bay to 20.

With the present study, the number of Tanaidacea species recorded for the Antarctica increases to 162 species, while the Colleteidae are represented by 16 species in six genera. The present work increases the knowledge of tanaidaceans for the Antarctica, especially in the deep-sea Antarctic area. 


\section{Acknowledgements}

The authors would like to thank Dr Lúcia de Siqueira Campos (Universidade Federal do Rio de Janeiro) who coordinated the field work and made the material available and to Dr Jim Lowry (Australian Museum) for revision of the manuscript. The first and last authors also thank CNPq (Conselho Nacional de Desenvolvimento Científico e Tecnológico) for financial support of the M.Sc. grant proc. no. $130986 / 2012-7$ and the productivity grant proc. no. 312343/2015-9, respectively.

\section{References}

Anderson G. 2013. Tanaidacea. In: Peracarida Taxa and Literature. Available from http://peracarida.usm.edu/iwp home.html [accessed 27 Jun. 2016].

Anderson G. \& Błażewicz-Paszkowycz M. 2014. Tanaidacea. In: Bamber R.N., El Nagar A. \& Arango C. (eds) Pycnobase: World Pycnogonida Database. Accessed through: De Broyer C., Clarke A., Koubbi P., Pakhomov E., Scott F., Vanden Berghe E. \& Danis B. 2015. Register of Antarctic Marine Species. Available from http://marinespecies.org/rams/aphia.php?p=taxdetails\&id=1133 [accessed 27 Jun. 2016].

Beddard F.E. 1886a. Preliminary notice of the Isopoda collected during the voyage of H.M.S 'Challenger.' Part III. Proceedings of the Zoological Society of London 26: 97-122.

Beddard F.E. 1886b. Report on the Isopoda collected by H.M.S. Challenger during the years $1873-$ 1876. Second part. Report on the Scientific Results of the Voyage of H.M.S. Challenger During the Years 1873-1876 [«Challenger Reports»] Zoology 17 (48): 1-178.

Bird G.J. 2007. Families Anarthruridae Lang, 1971, Colletteidae Larsen \& Wilson, 2002, and Leptognathiidae Sieg, 1976. In: Larsen K. \& Shimomura M. (eds) Tanaidacea (Crustacea: Peracarida) from Japan III. The deep trenches: the Kurile-Kamchatka trench and Japan trench. Zootaxa 1599: 61-85.

Błażewicz-Paszkowycz M. 2004. A description of a new species of Typhlotanais (Crustacea: Tanaidacea) from West Antarctic with a note on the genus. Zootaxa 535: 1-12. https://doi.org/10.11646/zootaxa.535.1

Błażewicz-Paszkowycz M. 2005. Singularia cuncta n. gen., n. sp. (Tanaidacea: Tanaidomorpha) from Antarctic abyssal waters. Journal of Crustacean Biology 25 (1): 75-80. https://doi.org/10.1651/C-2500

Błażewicz-Paszkowycz M. 2007. Colletteidae Larsen \& Wilson, 2002. World Register of Marine Species. Available from http://www.marinespecies.org/aphia.php?p=taxdetails\&id=237595 [accessed 27 Jun. 2016].

Błażewicz-Paszkowycz M. 2014. Tanaidacea. In: De Broyer C. \& Koubbi P. (eds) Biogeographic Atlas of the Southern Ocean: 173-180. Scientific Committee on Antarctic Research, Cambridge.

Campos L.S., Argeiro M.C.C., Bernardes M.C., Bromberg S., Callado R., Cipro C.V.Z., Dos Santos M.G., Fonseca M.M.C., Ignis B., Lange P.K. \& Salomão M.S.M.B. 2008. Boarding Report Antarctic Operation XXVII, Project MABIREH (Antarctic Marine Life: Biodiversity in Relation to Environmental Heterogeneity in Admiralty Bay, King George Island and adjacent areas). Rio de Janeiro.

Gardiner L.F. 1975. The systematics, postmarsupial development, and ecology of the deep-sea family Neotanaidae (Crustacea: Tanaidacea). Smithsonian Contributions to Zoology 170: 1-265.

Holdich D.M. \& Bird G.J. 1986. Tanaidacea (Crustacea) from sublittoral waters off West Scotland, including the Description of two new genera. Journal of Natural History 20 (1): 79-100. https://doi.org/10.1080/00222938600770081

Kudinova-Pasternak R.K. 1973. Tanaidacea (Crustacea, Malacostraca) collected on the R/V "Vitjas" in regions of the Aleutian Trench and Alaska. Trudy Instituta Okeanologii 91: 141-168. 
Lang K. 1971. Taxonomische und phylogenetische Untersuchungen über die Tanaidaceen. 6. Revision der Gattung Paranarthrura Hansen, 1913, und Aufstellung von zwei neuen Familien, vier neuen Gattungen und zwei neuen Arten. Arkiv för Zoologi 2 (23): 361-401.

Larsen K. 2003. Proposed new standardized anatomical terminology for the Tanaidacea (Peracarida). Journal of Crustacean Biology 23 (3): 644-661. https://doi.org/10.1651/C-2363

Larsen K. 2005. Deep-Sea Tanaidacea (Peracarida) from the Gulf of Mexico. Brill, Leiden.

Larsen K. \& Wilson G.D.F. 2002. Tanaidacean phylogeny, the first step: the superfamily Paratanaidoidea. Journal of Zoological Systematics and Evolutionary Research 40 (4): 205-222. https://doi.org/10.1046/j.1439-0469.2002.00193.x

Morales-Núñez A., Larsen K. \& Cooke W. 2016. Oahutanais makalii, a new genus and species of colletteid tanaidacean (Crustacea, Peracarida) from shelf-waters off Hawaii, with a taxonomic key. Zoosystematics and Evolution 92 (1): 1-12. https://doi.org/10.3897/zse.92.5581

Segadilha J.L. \& Araújo-Silva C.L. 2015. Two new species of Tanaopsis (Tanaidacea: Tanaopsidae) from Admiralty Bay (Antarctica), with an identification key. Nauplius 23 (1): 31-45. https://doi.org/10.1590/S0104-64972015002315

Shiino S.M. 1970. Paratanaidae collected in Chile Bay, Greenwich Island by the XXII Chilean Antarctic Expedition, with an Apseudes from Porvenir Point, Tierra del Fuego Island. Instituto Antartico Chileno, Serie Cientifica 1 (2): 77-122.

Shiino S.M. 1979. Tanaidacea collected by French Scientists on board the survey ship «MarionDufresne» in the regions around the Kerguelen Islands and other subantarctic islands in 1972, '74, '75, '76. Science Report of Shima Marineland 5: 1-122.

Sieg J. 1986. Crustacea Tanaidacea of the Antarctic and the Subantarctic. 1. On material collected at Tierra del Fuego, Isla de los Estados, and the west coast of the Antarctic Peninsula. In: Korniker L.S. (ed.) Biology of the Antarctic Seas 18. Vol. 45: Antarctic Research Series. American Geophysical Union, Washington, D.C.

Studer T. 1884. Isopoden, gesammelt während der Reise S.M.S Gazelle um die Erde, 1874-76. Abhandlungen der Königlichen Akademie der Wissenschaften zu Berlin: 1-28.

Manuscript received: 24 July 2016

Manuscript accepted: 13 February 2017

Published on: 7 November 2017

Topic editor: Rudy Jocqué

Desk editor: Kristiaan Hoedemakers

Printed versions of all papers are also deposited in the libraries of the institutes that are members of the EJT consortium: Muséum national d'Histoire naturelle, Paris, France; Botanic Garden Meise, Belgium; Royal Museum for Central Africa, Tervuren, Belgium; Natural History Museum, London, United Kingdom; Royal Belgian Institute of Natural Sciences, Brussels, Belgium; Natural History Museum of Denmark, Copenhagen, Denmark; Naturalis Biodiversity Center, Leiden, the Netherlands; Museo Nacional de Ciencias Naturales-CSIC, Madrid, Spain; Real Jardín Botánico de Madrid CSIC, Spain. 